council agreed to draw up a local ordinance setting out the conditions under which recombinant DNA research can be carried out in the city. Given the uncertainty, Genetics Institute has now withdrawn its application to build the laboratory.

Mr Hexner said last week that there would now inevitably be a delay in the company's plans. "It really depends on how long the deliberations go on and what the tenor of them is; if the tenor is favourable, then we would probably resubmit", he said. An alternative would be to look for a site in Cambridge itself. In sharp contrast with the debates of four years ago, when the then mayor Alfred Velucchi tried to ban all genetic engineering from the city, an ordinance passed in 1977 is being revised in relatively amicable circumstances.

The revisions have been precipitated by the decision of the Geneva-based Biogen Inc. to construct a new laboratory in Cambridge. Biogen's co-founder, Dr Walter Gilbert, is also a professor of molecular biology at Harvard and was a strong critic of the university's proposed involvement in Genetics Institute.

Biogen is now discussing with the local council the terms under which it will be allowed to operate its laboratory. And the Cambridge Biohazards Committee and the Cambridge Experimental Review Board are discussing a revision to the 1977 ordinance which would require, among other things, that any company or laboratory involved in recombinant DNA research should implement a medical surveillance scheme and a registry of its workers.

Such provisions have already been proposed by the Department of Labor's National Institute of Occupational Safety and Health, on the grounds that any longterm, relatively low-level effects could be traced only if adequate exposure records are kept of laboratory workers and the substances they handle. Biogen has said that it would have little difficulty in meeting such a requirement. More controversial could be the suggestion of a public debate on the acceptability of the site proposed for the laboratory.

Some members of the review board are also hoping to persuade the council to demand independent approval of the safety measures adopted by the company. This might be done by employing a consultant who would report to the city council but whose services would be partly paid for by the company.

A local ordinance including several of the proposed requirements has already been passed by the city council of Waltham, Massachusetts, home of the company Collaborative Genetics. As in Cambridge, the ordinance - which also covers research at Brandeis University - is primarily designed to ensure that all local recombinant DNA research is carried out under the safety guidelines developed by the National Institutes of Health.
In some respects, however, the ordinance is stricter than the guidelines. For example, it requires a formal medical surveillance procedure and the maintenance of work records and also prohibits the use of recombinant DNA products for trials on human patients.

With this model before them, other cities - including Newton, home of New England Nuclear - which are considering their own ordinances may find it difficult to adopt stricter rules. Mr Hexler, for example, says that Genetics Institute would be pleased to live with the Waltham ordinance and that if Somerville is too restrictive, "Waltham is there and waiting".

David Dickson

\section{Lamont director quits}

\section{Washington}

Columbia University in New York has forced the resignation of the director of the university's Lamont-Doherty Geological Observatory, Dr Mark Talwani, after complaints from senior faculty members about a lack of effective leadership.

Dr Talwani was asked by the university to resign shortly before Christmas. The university's decision was based partly on a report on the situation at the observatory, one of the world's leading centres of oceanic and seismic research, prepared by an outside committee under the chairmanship of Dr Karl K. Turekian of Yale University.

According to the university, the report praised a number of accomplishments of the observatory, but notes the existence of "serious problems" with Dr Talwani's leadership.

The committee itself did not recommend that Dr Talwani be replaced. But after further review and consultation with senior faculty members, including a meeting in October at which "almost all the senior faculty" is said by the university to have supported the search for an alternative director, Dr Talwani was asked to resign within two weeks.

Talwani himself vigorously protested at the university's decision, claiming that it had been the product of a "conspiratorial approach", and complaining to the university trustees that because no specific charges had been levelled against him, "I have had no opportunity to defend myself".

He eventually submitted his resignation as director two weeks ago, although he will remain on the university faculty as a member of its department of geological sciences. A search committee has been established to recommend a successor, and is expected to make its recommendation within a few days. Meanwhile Dr Paul G. Richards, associate director of the observatory, has been temporarily appointed its chief executive officer.

\section{Soviet fishing Whither whaling?}

The Soviet Far Eastern Fishing Fleet has ceased whaling operations in the Pacific, it was announced in Vladivostok last week. The three factory ships serving the fleet are now being converted into fish-processing plants.

This is the first stage in the implementation of a pledge given at the International Whaling Commission (IWC) meeting in California in December 1978. On that occasion, the Soviet delegate, Vyacheslav Zemskii, pledged his country to phase out all whaling within five years, starting with the North Pacific operation.

The announcement that three factory ships are being converted is, however, somewhat surprising. According to a Moscow radio broadcast shortly before the July 1980 IWC meeting, the Soviet Union had only two factory ships left, the Sovetskaya Rossiya and the Sovetskaya Ukrayina, both sailing from Vladivostok. Both of these ships, the commentator stressed, carried the necessary international observers as well as Soviet marine ecologists.

A partial phasing out of the North Pacific operation began some years ago. In 1979, when the Soviet Union accepted the IWC's partial moratorium, in which fishing from factory ships would be confined to Minke whales, it had already closed down its on-shore whaling stations, and had to negotiate an exchange with the Japanese, ceding its North Pacific quota of 230 Bryde whales in return for $\mathbf{3 0 0}$ of the less valuable Minke whales from the Antarctic.

The closedown of the North Pacific operation does not, however, necessarily mean that the Soviet Union will support the idea of a total moratorium. Soviet commentators have always taken the line that such a policy is not in accordance with the ecological facts, being based on a emotionalism encouraged by some quarters for political reasons. Greenpeace observers have described the Soviet whaling flotillas as near derelict hulks which would cost many millions of rubles to refit. This suggests that the planners have realized for some time that pro-moratorium pressure might well force the Soviet whaling flotillas to disband, and that it was not therefore cost effective to keep the ships in trim.

With the recent drive for self-sufficiency in raw materials, stressed at the October 1980 Central Committee Plenum and in the Guidelines for the new Five Year Plan, what will the Soviet Union use to replace whale-oil?. One possibility is the jojoba, which would probably thrive in the semiarid steppes of Soviet Asia. Unfortunately, the jojoba plant is dioecious, and, in the natural state, male plants predominate. Jojoba culture is therefore highly labourintensive, involving the vegetative propagation of large numbers of female 